\title{
Serum Copper and Plasma Protein Status in Normal Pregnancy
}

\author{
Nushrat Noor ${ }^{1}$, Nasim Jahan ${ }^{2}$, Nayma Sultana ${ }^{3}$
}

\begin{abstract}
Background: Gradual alteration of serum copper and some plasma protein levels may occur with advancement of pregnancy, which is associated with increased maternal and infant morbidity and mortality. Objective: To observe serum copper and plasma protein levels in normal pregnant women of different trimesters in order to find out their nutritional status. Methods: This cross sectional study was carried out in the Department of Physiology, Sir Salimullah Medical College (SSMC), Dhaka, between $1^{\text {st }}$ January 2010 and December 2010. Ninety normal pregnant women of different trimesters with age 20-30 years were included in the study group. They were selected from Out Patient Department of Obstetrics and Gynaecology, SSMC. Age matched 30 non-pregnant women were taken as control. Serum copper level was measured by Spectrophotometric method, serum total protein and albumin levels were estimated by standard method. Statistical analysis was done by one way ANOVA, Bonferroni and Pearson's correlation coefficient test as applicable. Results: Serum Cu levels were significantly higher in all trimesters of pregnant women compared to control. Again, this value was significantly higher in $3^{\text {rd }}$ trimester than that of in $1^{\text {st }}$ and $2^{\text {nd }}$ trimester and also in $2^{\text {nd }}$ trimester than that of in $1^{\text {st }}$ trimester. In addition, mean serum total protein level was significantly lower in $3^{\text {rd }}$ trimester than control but no statistically significant difference was observed among different trimesters. Again, mean serum albumin level was significantly lower in $2^{\text {nd }}$ and $3^{\text {rd }}$ trimester than $1^{\text {st }}$ trimester and control. In addition, serum $\mathrm{Cu}$ concentration showed significant positive correlation with different trimesters of gestation. Conclusion: This study reveals that hypercupremia along with hypoproteinemia occur in pregnant women from $1^{\text {st }}$ to $3^{\text {rd }}$ trimester of gestation. This gradual alteration of micro and macronutrients become more profound with advancement of pregnancy.
\end{abstract}

Key words: Serum copper, Plasma protein, Trimester, Pregnancy.

J Bangladesh Soc Physiol. 2012 December; 7(2): 66-71 For Authors Affiliation, see end of text.

http://www.banglajol.info/index.php/JBSP

\section{Introduction}

$\mathbf{P}$ regnancy is a period of increased metabolic demands, with changes in the woman's physiology and the requirements of a growing fetus ${ }^{1}$. During this time, improper stores or intake of micronutrients can have adverse effects on the mother such as anemia, hypertension, complication of labor and even death ${ }^{2}$. Furthermore the fetus can be affected resulting in stillbirth, pre-term delivery, IUGR,

Received: August 2012; Accepted: November 2012 congenital malformation and abnormal organ development $^{3,4}$.

Nutritional status in early pregnancy may be an important indicator of nutritional risk in late pregnancy ${ }^{5}$. Fetal demand for nutrients occurs primarily during the last half of gestation when $>90 \%$ of fetal growth occurs ${ }^{6}$. Circulating concentrations of most nutrients decrease by the end of first 10 weeks of gestation and remain lower than non pregnant values until term ${ }^{1}$. 
Different researchers demonstrated that micro and macro nutrients are essential for the development of fetus. In pregnancy many minerals like zinc, copper, calcium and magnesium are transferred from mother to the fetus ${ }^{3}$.

Copper is essential for neural function ${ }^{7}$. It forms an integral component of many metalloenzymes including amine oxidase, cytochrome oxidase, super-oxide dismutase and tyrosinase ${ }^{8}$. In addition, copper is also involved in the synthesis of hemoglobin ${ }^{9}$, formation of collagen, skeletal development ${ }^{7}$, maintenance of the myelin sheath and in immune function ${ }^{10}$. Maternal copper deficiency can cause infertility, abortion and still birth $^{11}$. Copper deficiency during pregnancy can result in delivery of offspring with congenital abnormalities of the nervous system ${ }^{11}$. It has been reported that more than $50 \%$ of human conception fail to implant and of those implanted, approximately $30 \%$ fail to reach term due to copper deficiency ${ }^{12}$. However, during pregnancy serum copper level increases from about 80 to $155 \mu \mathrm{g} / \mathrm{dl}$ to about 118 to $302 \mu \mathrm{g} / \mathrm{dl}$ by the end of the $3^{\text {rd }}$ trimester ${ }^{9}$. This increase of copper may be due to an increase of ceruloplasmin as a result of elevated level of estrogen during pregnancy ${ }^{13}$. Again, less diffusion of maternal serum $\mathrm{Cu}$ through the placenta may also cause hypercupremia in pregnant women ${ }^{3}$. However, excess copper level in pregnancy can be associated with intrauterine growth retardation in fetus and preeclampsia along with some neurological diseases in mother ${ }^{14}$. Moreover, persistently high copper levels may contribute to postpartum depression due to the effects of metals on nervous tissue. Excess copper in the brain, can alter the balance of dopamine and norepinephrine, two mood-regulating neurotransmitters ${ }^{15}$.

It has been observed that copper level was significantly higher in pregnant women than that of non pregnant women. They also found that copper level increased gradually and significantly from the $1^{\text {st }}$ trimester to the $3^{\text {rd }}$ trimester. The maximum increased level of copper was observed during $3^{\text {rd }}$ trimester of pregnancy ${ }^{16}$. Some other group of investigators also reported that pregnant women of 28 to 32 weeks of gestation had lower serum copper levels in comparison to the pregnant women of gestational age 32 to 36 weeks. A significant positive correlation was found between gestational age and serum copper level ${ }^{4}$. On the contrary, a decreased serum $\mathrm{Cu}$ level was also found in $3^{\text {rd }}$ trimester when compared to that of in $1^{\text {st }}$ and $2^{\text {nd }}$ trimester of normal pregnant women ${ }^{17}$.

Furthermore, some nutritional deficiencies such as deficiency of protein, vitamins etc. may also be responsible for preterm delivery especially in developing countries ${ }^{5}$. In addition to this, protein deficiency especially deficiency of albumin and globulin may also be responsible for alteration of maternal plasma $\mathrm{Cu}$ concentration, as they act as $\mathrm{Cu}$-binding vehicle ${ }^{18}$. Some researchers found significantly lower levels of serum total protein and albumin in some pre-term mother in comparison to those of non- pregnant women and also of full-term mother ${ }^{19}$. So, pregnancy is often associated with adequate level of all the nutrients like iron, copper, zinc, proteins etc. and inappropriate supply of one of these may affect pregnancy, delivery and outcome of pregnancy ${ }^{13}$.

A change of micro and macronutrient status in women of reproductive age is recognized as a major public health problem in our country. Pregnant women are vulnerable to nutritional deficiencies because of the increased demand during pregnancy. Although some work on role of copper and plasma proteins on preterm delivery ${ }^{19}$ was done in our country, but little is known about serum copper and protein levels in different trimesters of normal pregnancy. 
Therefore, the present study has been undertaken to estimate serum copper and protein concentrations in different trimesters of gestation. It is expected that findings of this study would give a guideline to the obstetrician for better management of the pregnant women which may prevent maternal and fetal morbidity and mortality and also may reduce the risk of complication during and after delivery.

\section{Methods}

This cross sectional study was carried out in the Department of Physiology, Sir Salimullah Medical College (SSMC), Dhaka between $1^{\text {st }}$ January 2010 and $31^{\text {st }}$ December 2010. Study subjects were selected by following simple random sampling procedure and the protocol of this study was approved by Institutional Ethics Committee (IEC) of SSMC. Total number of 90 normal pregnant women of different trimesters age 20-30 years was enrolled in the study group (Group B). They were subdivided into group $\mathrm{B}_{1}(\mathrm{n}=30) 1^{\text {st }}$ trimester, group $\mathrm{B}_{2}(\mathrm{n}=30) 2^{\text {nd }}$ trimester and group $\mathrm{B}_{3}(\mathrm{n}=30)$ $3^{\text {rd }}$ trimester. Age matched 30 apparently healthy non-pregnant women (group A) was served as control group. The pregnant women were collected from Out Patient Department of and Obstetrics and Gynaecology, SSMC and nonpregnant women by personal contact. Serum copper level was measured by Spectrophotometric method ${ }^{20}$, serum total protein and albumin levels were estimated by standard laboratory method. The statistical analysis was done by One- way ANOVA (Post Hoc), Bonferroni and Pearson's correlation coeeficient test by using SPSS, version- 16.

\section{Results}

All the groups were matched for age. Mean $(+\mathrm{SD})$ of Age and BMI of different groups are shown in (Table I).
The mean $( \pm \mathrm{SD})$ serum Cu level was significantly higher in all groups of pregnant women than that of non-pregnant women. Again, this value was significantly $(\mathrm{p}<0.001)$ higher in $3^{\text {rd }}$ trimester than that of $1^{\text {st }}$ and $2^{\text {nd }}$ trimester and also in $2^{\text {nd }}$ trimester than that of $1^{\text {st }}$ trimester (Table II).

Again, mean serum total protein level was significantly $(\mathrm{p}<0.01)$ lower in $3^{\text {rd }}$ trimester than that of non-pregnant women. Whereas, this level was almost similar and no statistically significant difference was observed among the other groups. Again, mean serum albumin level was significantly lower in $2^{\text {nd }}$ and $3^{\text {rd }}$ trimester than that of non-pregnant women $(\mathrm{p}<0.001)$ and also of $1^{\text {st }}$ trimester $(\mathrm{p}<0.05)$. Whereas mean serum globulin level was almost similar and showed no statistically significant difference of this value among the groups (Table II).

Table I: Age and Body Mass Index (BMI) in different groups $(\mathrm{n}=120)$

\begin{tabular}{lll}
\hline Groups & Age (years) & BMI $\left(\mathrm{kg} / \mathrm{m}^{2}\right)$ \\
\hline $\mathrm{A}(\mathrm{n}=30)$ & $25.43 \pm 3.24$ & $23.94 \pm 1.15$ \\
$\mathrm{~B}_{1}(\mathrm{n}=30)$ & $24.60 \pm 3.11$ & $27.72 \pm 3.27$ \\
$\mathrm{~B}_{2}(\mathrm{n}=30)$ & $24.43 \pm 3.32$ & $29.11 \pm 2.75$ \\
$\mathrm{~B}_{3}(\mathrm{n}=30)$ & $24.63 \pm 3.52$ & $30.82 \pm 2.54$ \\
\hline
\end{tabular}

Data are expressed as mean + SD. For statistical analysis, one way ANOVA test was done for comparison among the groups and then Bonferroni test to compare between the groups.

Group A: Apparently healthy non pregnant women Group B: Pregnant women

Group $\mathrm{B}_{1}: 1^{\text {st }}$ trimester of gestation.

Group $\mathrm{B}_{2}: 2^{\text {nd }}$ trimester of gestation.

Group $B_{3}: 3^{\text {rd }}$ trimester of gestation.

Moreover, serum $\mathrm{Cu}$ concentration was positively correlated $(\mathrm{r}=0.784)$ with different trimesters of gestation and this relationship was statistically significant $(\mathrm{p}<0.001)$ (Figure 1). 
Table II: Serum copper and plasma protein levels in different groups $(\mathrm{n}=120)$

\begin{tabular}{|c|c|c|c|c|}
\hline Groups & Copper( $\mu \mathrm{g} / \mathrm{dl})$ & Total Protein $(\mathrm{g} / \mathrm{dl})$ & $\operatorname{Albumin}(\mathrm{g} / \mathrm{dl})$ & Globulin(g/dl) \\
\hline$A(n=30)$ & $102.33 \pm 10.98$ & $6.92 \pm 0.98$ & $4.30 \pm 0.71$ & $2.61 \pm 0.88$ \\
\hline $\mathrm{B}_{1}(\mathrm{n}=30)$ & $118.00 \pm 18.71$ & $6.61 \pm 1.00$ & $3.97 \pm 0.64$ & $2.64 \pm 0.75$ \\
\hline $\mathrm{B}_{2}(\mathrm{n}=30)$ & $147.90 \pm 21.60$ & $6.31 \pm 1.02$ & $3.53 \pm 0.53$ & $2.78 \pm 0.77$ \\
\hline $\mathrm{B}_{3}(\mathrm{n}=30)$ & $186.90 \pm 28.42$ & $6.01 \pm 0.94$ & $3.53 \pm 0.54$ & $2.49 \pm 0.70$ \\
\hline \multicolumn{5}{|c|}{ Statistical analysis } \\
\hline Groups & $\begin{array}{l}\text { Copper } \\
\text { (p value) }\end{array}$ & $\begin{array}{l}\text { Total Protein } \\
\text { (p value) }\end{array}$ & $\begin{array}{l}\text { Albumin } \\
\text { (p value) }\end{array}$ & $\begin{array}{l}\text { Globulin } \\
\text { (p value) }\end{array}$ \\
\hline$\overline{A v s B_{1}}$ & $0.026^{*}$ & $0.999^{\text {ns }}$ & $0.230^{\mathrm{ns}}$ & $0.999^{\text {ns }}$ \\
\hline$A$ vs $B_{2}$ & $0.000 * * *$ & $0.111^{\text {ns }}$ & $0.000 * * *$ & $0.999^{\text {ns }}$ \\
\hline $\mathrm{A}$ vs $\mathrm{B}_{3}$ & $0.000 * * *$ & $0.003 * *$ & $0.000 * * *$ & $0.999^{\mathrm{ns}}$ \\
\hline $\mathrm{B}_{1} \mathrm{vs} \mathrm{B}_{2}$ & $0.000 * * *$ & $0.999^{\text {ns }}$ & $0.037^{*}$ & $0.999^{\mathrm{ns}}$ \\
\hline $\mathrm{B}_{1} \mathrm{vs} \mathrm{B}_{3}$ & $0.000 * * *$ & $0.123^{\mathrm{ns}}$ & $0.032 *$ & $0.999^{\text {ns }}$ \\
\hline $\mathrm{B}_{2} \mathrm{vs} \mathrm{B}_{3}$ & $0.000 * * *$ & $0.999^{\text {ns }}$ & $0.999^{\text {ns }}$ & $0.907^{\mathrm{ns}}$ \\
\hline
\end{tabular}

Data are expressed as mean $+\mathrm{SD}$. For statistical analysis, one way ANOVA test was done for comparison among the groups and then Bonferroni test to compare between the groups.

Group A: Apparently healthy non pregnant women

Group B: Pregnant women

Group $\mathrm{B}_{1}: 1^{\text {st }}$ trimester of gestation.

Group $\mathrm{B}_{2}: 2^{\text {nd }}$ trimester of gestation.

Group $\mathrm{B}_{3}: 3^{\text {rd }}$ trimester of gestation.

$* * *=\mathrm{p}<0.001 \mathrm{~ns}=$ not significant, $\mathrm{p}>0.05$

$* *=\mathrm{p}<0.01 \quad \mathrm{n}=$ number of subjects.

$*=p<0.05$

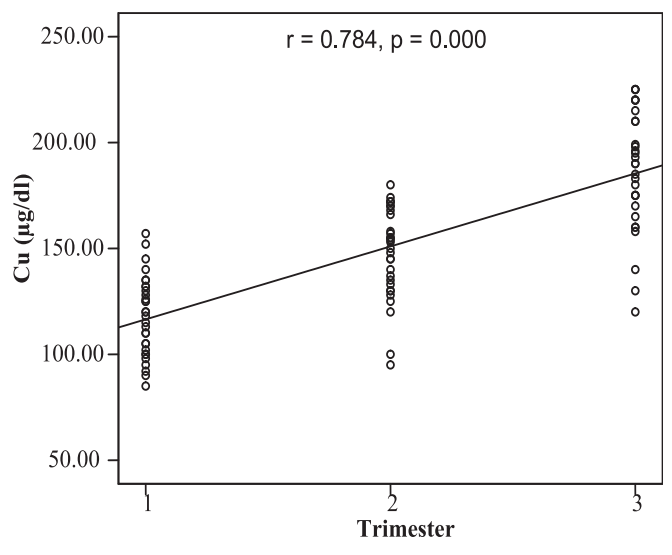

Figure 1: Correlation of Serum Copper concentration with trimesters of gestation $(n=90)$

\section{Discussion}

In the present study, increased serum $\mathrm{Cu}$ level has been found during different trimesters of pregnant women and maximum increased value was observed in $3^{\text {rd }}$ trimester. This finding is in consistent with that of some other researchers ${ }^{21,16}$. On the contrary, serum Cu level was found lower in $3^{\text {rd }}$ trimester of gestation when compared to that of in $1^{\text {st }}$ and $2^{\text {nd }}$ trimester of pregnant women. The researchers suggested that this might be due to hemodilution ${ }^{17}$. Again, serum $\mathrm{Cu}$ concentration has shown significant positive correlation with different trimesters of gestation in present study. Similar observation is also made by other investigators ${ }^{16}$. 
However, hypercupremia during $3^{\text {rd }}$ trimester of pregnancy may be due to mobilization of copper from maternal tissues, especially from the liver for its utilization during fetal development ${ }^{21}$. Again, it has been suggested that increased serum $\mathrm{Cu}$ during $3^{\text {rd }}$ trimester of pregnancy may be due to increase in carrier protein, ceruloplasmin in response to elevated level of estrogen ${ }^{13}$. In addition to this decreased biliary copper excretion induced by hormonal changes, may lead to an increase in serum $\mathrm{Cu}$ level during pregnancy ${ }^{10}$. Moreover, an inverse metabolic relationship exists between zinc and copper which may also be responsible for elevated plasma copper levels in the presence of lower plasma zinc during pregnancy ${ }^{22}$. During last months of pregnancy the plasma progesterone exceeds the normal limit. This hormone increases plasma copper, necessary for placental maturation $^{4}$.

In addition, in the present study a gradual decrease in total protein and albumin levels were also observed in different trimesters of pregnancy. It has been suggested that, pregnant women in developing countries consume diets with a lower quantity of protein, minerals and vitamins ${ }^{23}$. This inadequate dietary intake may be responsible for hypoproteinemia and hypoalbuminemia during pregnancy $^{2}$.

In the present study, a gradual increase in serum copper level was observed in pregnant women of different trimesters, which was more pronounced in $3^{\text {rd }}$ trimester. This high serum $\mathrm{Cu}$ level in pregnant women of the present series are may be due to increased concentration of ceruloplasmin in response to stimulation by elevated level of estrogen during pregnancy. But this cannot be elucidated from the present study as serum concentration of ceruloplasmin was not measured. Furthermore, significant positive correlation of serum $\mathrm{Cu}$ level with different trimesters of gestation indicating the changes of this micronutrient on each trimester of gestation which is more marked in $3^{\text {rd }}$ trimester. Again, hypoproteinemia and hypoalbuminemia of the study subjects indicating their poor nutritional status. However, the exact mechanism involved for this gradual alteration of serum copper and plasma protein level in different trimesters of pregnancy cannot be find out from this type of study due to time and financial constrains. So, a further study on this field is required for clarification.

\section{Conclusion}

From this study, it can be concluded that gradual hypercupremia and hypoproteinemia occur in pregnant women from $1^{\text {st }}$ to $3^{\text {rd }}$ trimester of gestation. This gradual alteration of micro and macronutrients become more profound with advancement of pregnancy may be due to their nutritional deficiency and high demand during pregnancy.

\section{Acknowledgement}

Authors of this study are thankful to the authority of Department of Biochemistry, BSMMU for the cooperation regarding laboratory facility they provided. The authors acknowledge the partial financial support from the research grant of DGHS of Bangladesh. The authors are also thankful to all of study subjects for their active and cordial cooperation to carry out the study .

\section{Author Affiliations}

1. *Nushrat Noor, Assistant Professor, Department of Physiology, Dhaka Central International Medical College, Dhaka. E-mail: noor.nushrat@gmail.com

2. Professor Nasim Jahan, Professor and Head, Department of Physiology, Sir Salimullah Medical College, Mitford, Dhaka. E-mail: prof.dr. nasimjahan@gmail.com

3. Nayma Sultana, Associate Professor, Department of Physiology, Sir Salimullah Medical College, Mitford, Dhaka. E-mail: nayma_sultana@ yahoo.com

* For correspondence

\section{References}

1. King JC. Physiology of pregnancy and nutrient metabolism. The American Journal of Clinical Nutrition. 2000; 71: 1218-1225.

2. Ramakrishnan U, Manjrekar R, Rivera J, GonjalesCossio T, Martorell R. Micronutrients and 
pregnancy outcome: a review of the literature. Nutrition research. 1999; 19: 103-159.

3. Black RE. Micronutrients in pregnancy. British Journal of Nutrition. 2001; 85: 193-197.

4. Pathak P, Kapil U. Role of trace elements zinc, copper and magnesium during pregnancy and its outcome. Indian Journal of Pediatrics. 2004; 71: 1003-1005.

5. Bruinse HW, Van den Berg H. Changes of some vitamin levels during and after normal Pregnancy. Eur J Obstet Gynecol Repord Biol. 1995; 61: 3137.

6. Hytten F, Chamberlain G. Clinical Physiology in Obstetrics. $2^{\text {nd }}$ ed. Oxford United Kingdom: Blacwell Scientific Publications; 1980. 580p.

7. Cengiz B, Soylemez F, Ozturk E, Cavdar AO. Serum zinc, selenium, copper and lead levels in women with second trimester induced abortion resulting from neural tube defects: A preliminary study. Biol Trace Elem Res. 2004; 97: 225-235.

8. Murray RK. Plasma proteins and immunoglobulins. In: Murray RK, Granner DK, Rodwell VW, editor. Harper's Illustrated Biochemistry. Boston: McGrawHill Company; 2006. p. 588-605.

9. Hsu JM, Karcioglu ZA, Sarper RM, Charles C, Thomas. Zinc and copper in medicine. Sprinfield. 1980; 7: 66-93.

10. Keen CL, Uriu-Hare JY, Hawk SN, Jankowski MA, Daston GP, Kwik-Uribe CL, Rucker RB. Effect of copper deficiency on prenatal development and pregnancy outcome. Am J Clin Nutr. 1998; 67: 1003-1011.

11. Davis GK, Mertz W. Copper. In: Mertz W, editor. Trace Elements in Human and Animal Nutrition. California: Academic press; 1987. p. 301-364.

12. Kimmel C, Generose W, Thomas R, Bakashi K. A new frontier in understanding mechanism of developmental abnormalities. Toxicol Appl Pharm. 1993; 119: 159-165.

13. Upadhyayan C, Mishra S, Ajmera P, Sharma P. Serum iron, copper and zinc status in maternal and cord blood. Indian Journal of Clinical Biochemistry. 2004; 19(2): 48-52.

14. Young T, Downey G, Maheshwari M, Nicholl D. A cupric pregnancy-thirteenth time lucky. Journal of Royal Society of Medicine Short. 2010; 1(6): 51.

15. Crayton JW, Walsh WJ. Elevated serum copper levels in women with a history of postpartum depression. J Trace Elem Med Biol. 2007; 21(1): $17-21$.

16. Al-Bader A, Hussain T, Al-Mosawi M, Otaibi M, Abul H, Khalifa, Dashti H. Serum zinc and copper concentrations in pregnant women from Kuwait. The Journal of Trace Elements in Experimental Medicine. 1997; 10: 209-215.

17. Huang HM, Leung PL, Sun DZ, Zhu MG. Hair and serum calcium, iron, copper and zinc levels during normal pregnancy at three trimesters. Biological Trace Element Research. 1999; 69: 111-120.

18. Perveen S, Altaf W, Vohra N, Bautista ML, Harper RG, Wapnir RA. Effect of Gestational Age on Cord Blood Plasma Copper, Zinc, Magnesium and Albumin. Early Human Development. 2002; 69: 15-23.

19. Sultana M, Jahan N, Sultana N, Akter R. Serum Copper and Plasma Protein Status in Preterm delivery. J Bangladesh Soc Physiol. 2012; 7(1): 41-47.

20. Smith JC, Butrimovitz GP, Purdy WC. Direct measurement of zinc and copper in plasma by Atomic Absorption Spectroscopy. Clin Chem. 1979; 25 (8): 1487-1491.

21. Liu J, Yang H, Shi H, Shen C, Zhou W, Dai Q, Jiang Y. Blood copper, zinc, calcium and magnesium levels during different duration of pregnancy in Chinese. Bio Trace Elem Res. 2010; 135: 31-37.

22. Sandstorm B. Micronutrient interactions: Effects on absorption and bioavailability. British Journal of Nutrition. 2001; 85: 181-185.

23. Mahan LK, Escott-Stump S. Nutrition During Pregnancy and Lactation. In: Krause's. Food, Nutrition And Diet Therapy. Philadelphia: WB Saunders company; 2004. p. 183-189. 